\title{
Dynamic Villages in the Hinterland of a Polycentric Region: Case Study of the Górnośląsko-Zagłębiowska Metropolis in Poland
}

\author{
Elżbieta Zuzańska-Żyśko *®i] and Marlena Dyszy
}

Citation: Zuzańska-Żyśko, E.; Dyszy, M. Dynamic Villages in the

Hinterland of a Polycentric Region: Case Study of the GórnoślaskoZagłębiowska Metropolis in Poland. Land 2021, 10, 779. https://doi.org/ 10.3390/land10080779

Academic Editors: Roberto Henke and Francesco Vanni

Received: 22 June 2021

Accepted: 22 July 2021

Published: 25 July 2021

Publisher's Note: MDPI stays neutral with regard to jurisdictional claims in published maps and institutional affiliations.

Copyright: (c) 2021 by the authors. Licensee MDPI, Basel, Switzerland. This article is an open access article distributed under the terms and conditions of the Creative Commons Attribution (CC BY) license (https:// creativecommons.org/licenses/by/ $4.0 /)$.
Institute of Social and Economic Geography and Spatial Management, Faculty of Natural Sciences, University of Silesia in Katowice, ul. Będzińska 60, 41-200 Sosnowiec, Poland; marlena.dyszy@gmail.com

* Correspondence: elzbieta.zuzanska-zysko@us.edu.pl; Tel.: +48-323-689-484

Abstract: This article examines the growth of the labour market and entrepreneurship in a metropolitan area. In particular, the study attempts to answer how the economy of the rural regions is developing in the hinterland of a large urban complex in Southern Poland, which is transforming from a post-industrial conurbation into a metropolitan area. The study applied Florence's local specialization index, statistical measures, dynamics indexes, and Pearson's correlation index. The research results show that the local economy, including the labour market, is systematically growing. Rural communes refer to multifunctional development based on services, and they represent diverse economic specializations. They are subject to economies of scale and benefit from the proximity and impact of a large urban complex. The economic growth of rural areas in the hinterland is related to entrepreneurship, convenient location in relation to cities, and migration from cities to villages.

Keywords: rural areas; metropolitan area; polycentric region; local economy; entrepreneurship

\section{Introduction}

In the countries of Western Europe, functional and spatial transformations of the suburban area began many decades ago, but in the Central and Eastern part, these processes began much later and are related to the systemic transformation [1]. However, it seems that at present, trends are similar all over Europe, and suburban areas are subject to intensive spatial transformations [2-10], strong economic pressure [11-14] and landscape [15-23]. The areas near metropolitan centres, where migrations exert strong pressure, are the most transformed in Europe [24,25]. In the OECD, between 2000 and 2007, rural regions close to cities recorded an average annual productivity increase of 2.15\% [26]. In 2015, metropolitan regions contributed to almost $72 \%$ of the EU-28's GDP, whereas just less than $60 \%$ of the total EU population is living in metropolitan regions [27]. Meijers and Wouw [28] argued that rural areas create networks with surrounding metropolitan regions and take advantage of some of the benefits they offer, as well as "borrow" some of their "size". These conditions make the areas at the junction of large cities an extremely interesting research field, and this require an in-depth local analysis in a wider urban context.

With the above in mind, the study attempts to answer the question of how the economy of rural areas is developing in the hinterland of a large urban complex in Southern Poland, which is transforming from a polycentric post-industrial conurbation into a metropolitan area. For this purpose, a hypothesis was adopted that rural communes located in the hinterland of the Górnoślasko-Zagłębiowska Metropolis are subject to economic urbanization and in turn take advantage of the associated agglomeration benefits, which allow the communes to increase the labour market and show diversified specialization of the economy. The results of the analysis are presented in three aspects: (1) the labour market and the dynamics thereof are analysed; (2) the activity of the local potential and economic specialization are examined, while referring to the concept of multifunctional development; 
(3) and the factors of entrepreneurship development and economic growth are identified. In terms of structure, the article begins with a presentation of the rural areas in Poland; it then discusses the role of migration in shaping economic processes in suburban zones and then analyses the areas of the selected case studies. On the whole, the study represents a geographical approach in the functional and spatial trend.

The growth of the rural labour market and entrepreneurship in metropolitan areas attracts less attention of researchers, and therefore this study contributes to deepening the knowledge about the local economy at the junction of a large urban complex. The labour market is one of the basic features determine the level of economic development. It is connected with economic urbanization and influences functional changes. A wellfunctioning labour market in the countryside is of key importance as it contributes to a more effective division of labour in the economy [29]. Rural urbanization causes a shift away from the traditional agricultural region and a shift to a service and consumption region, i.e., an increase in the share of people living off their farms. Simultaneously, the employment structure in rural areas is strongly limited by the regional labour market [30], which contributes to its transformation in a relatively short time, which in turn leads to multifunctional development. In the hinterland of the metropolis, villages can play a complementary role and even fill various production niches. This is due to the variety of connections with agriculture and the openness of still free areas for new investments. The big city market places different demands on rural areas in their hinterland compared to peripheral villages. This creates more development opportunities in rural labour markets and strengthens local business. At the end of the 1990s, 35\% of economic entities in rural areas in Poland were characterized by non-agricultural functions due to their location in relation to cities, their better infrastructure development, and the population potential and education of the inhabitants [31].

\section{Study Area}

The spatial scope of the study concerns rural communes in the hinterland of a metropolitan area with over two million inhabitants located in the Ślaskie Voivodeship in Southern Poland. This area has the genesis of a mining and industrial conurbation. A significant part of the described structure is known in the literature as the Katowice conurbation [32-36] and the Upper Silesian conurbation [37-39]. An essential element is that the region in the past was associated with mining, metallurgy, and heavy industry for 200 years, and now it shows the first signs of metropolisation [40]. In 2017, under the Act on the Metropolitan Union, the area took the legal and organizational form under the name of the Górnoślasko-Zagłębiowska Metropolis (GZM for short). Since 2018, the area has been managed by the Metropolitan Office [41]. It consists of the urbanized and compact functional and spatial space of 41 municipalities (Figure 1). Katowice is the main centre. The core is a community of 13 cities with poviat rights with a population of 49.1 to 290.6 thousand residents. Together, these cities have 1.7 million inhabitants (Table 1). Other poviat towns, small towns, and rural communes border the multicentre core. It is the first established metropolitan structure in Poland under the Act. It receives 5\% of the income from the tax on natural persons residing in its territory. The budget is also supplemented by membership fees of the cities and communes that make up the GZM. The tasks of the GZM include four main aspects: (1) public transport management, (2) socio-economic development, (3) shaping the spatial order, and (4) promoting its potential.

Eight rural communes located at the junction of the polycentric core were selected for the study (Figure 1). These are Bobrowniki and Psary (NUTS 3 Będzin poviat), Świerklaniec and Zbrosławice (NUTS 3 Tarnogórski poviat), Gierałtowice (NUTS 3 Gliwice poviat), Wyry (NUTS 3 Mikołów poviat), Kobiór (NUTS 3 Pszczyna poviat), and Chełm Śląski (NUTS 3 Bieruńsko-Lędziński poviat). The communes consist of smaller villages (village administrations), some of them are highly dispersed and of various sizes. At the same time, they have different functions and communication accessibility, but all of them are subject to 
strong migratory pressure from and bordering the core cities of the GZM. Cities affecting the analysed rural areas are of different sizes and ranks in the settlement hierarchy [42,43].

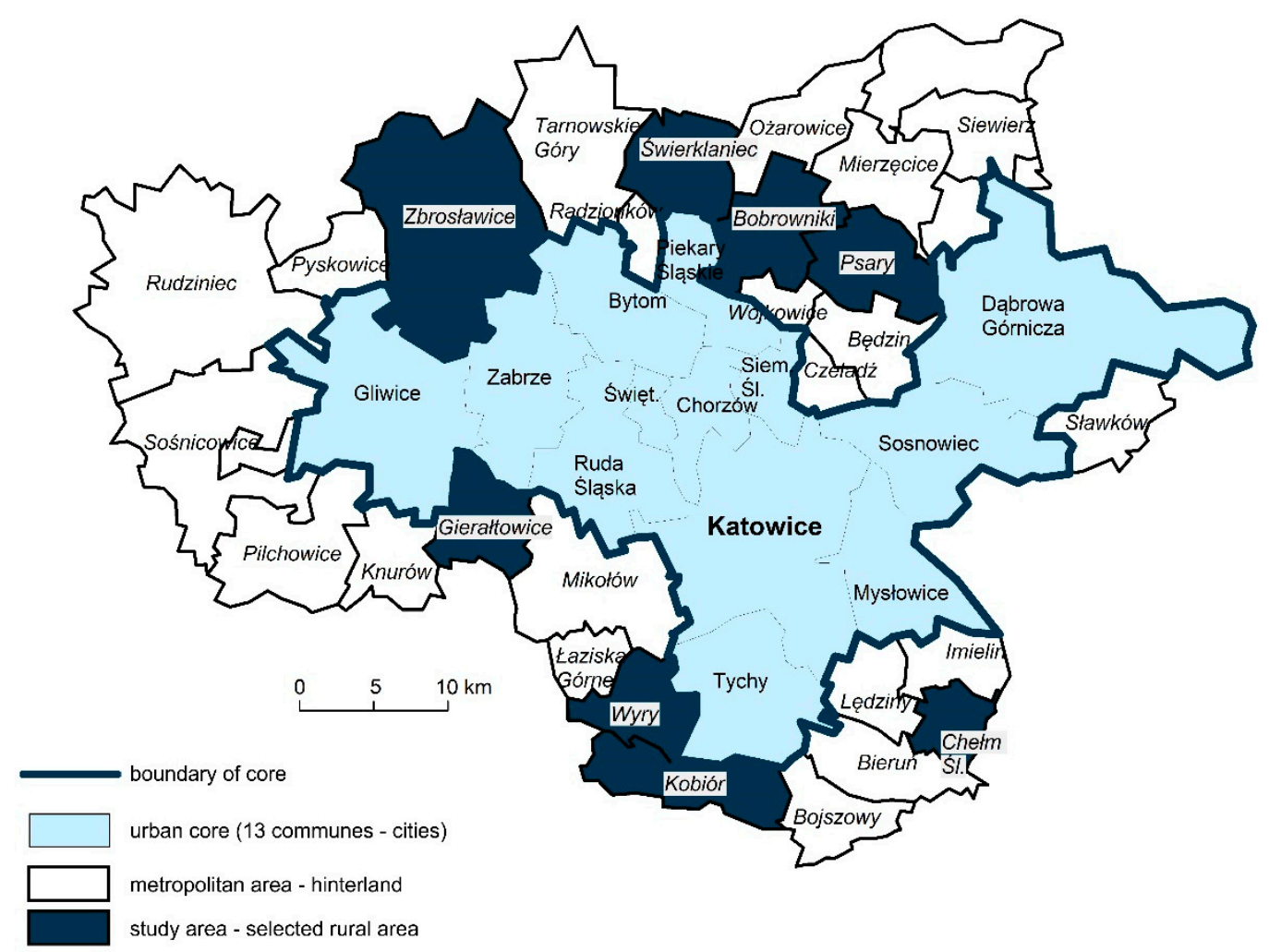

Figure 1. Study area with the selected rural communes in the hinterland of the Górnośląsko-Zagłębiowska Metropolis $(\mathrm{GZM})$.

Table 1. Population and area of the GZM in 2018.

\begin{tabular}{|c|c|c|c|}
\hline Górnośląsko-Zagłębiowska Metropolis (GZM) & Population & Area $\left[\mathrm{km}^{2}\right]$ & $\begin{array}{c}\text { Population Density } \\
\left.\text { [Person } / \mathbf{k m}^{2}\right]\end{array}$ \\
\hline GZM, metropolitan area (total 41 communes) & $2,229,806$ & 2376 & 938 \\
\hline $\begin{array}{l}\text { Core (13 cities): Katowice, Gliwice, Sosnowiec, Bytom, Tychy, } \\
\text { Zabrze, Chorzów, Dábrowa Górnicza, Mysłowice, Siemianowice } \\
\text { Śląskie, Ruda Śląska, Piekary Śląskie, Świętochłowice }\end{array}$ & $1,732,431$ & 1065 & 1625 \\
\hline $\begin{array}{c}\text { Towns at hinterland: Tarnowskie Góry, Mikołów, Będzin, Knurów, } \\
\text { Bierun, Lędziny, Imielin, Radzionków, Wojkowice, Pyskowice, } \\
\text { Łaziska Górne, Sławków, Siewierz, Sośnicowice }\end{array}$ & 367,575 & 515 & 714 \\
\hline The rural area of hinterland & 129,800 & 796 & 163 \\
\hline
\end{tabular}

The choice of research area is dictated by several factors: (1) all municipalities are located in the hinterland of the GZM and border large and medium-sized cities; (2) they are diversified in terms of population number and their spatial distribution; (3) they are characterized by a different size and type of settlement network (both dispersion and relative concentration); (4) a national or international road runs through each commune; (5) the research area is diversified in terms of the level of urbanization and agricultural activity; (6) they are adjacent to at least one city with poviat rights. 


\section{Materials and Methods}

The time scope of the study covers the years 1995-2016. The work uses statistical data from the Central Statistical Office in Katowice, the BDL Local Data Bank database [44]. The data mainly comprise:

- number of economic entities in 1995-2016 (BDL), including those broken down into PKD sections;

- number of employed persons in 2003 and 2010, 2016 (unpublished data for small, medium and large entities);

- directions of migration from cities to rural communes in 2002-2015.

On the basis of the collected materials about economic entities, the economic activity of the surveyed communes was determined, and the dynamics of the entrepreneurship index for the years 1995-2016 were determined, as well as changes in the labour market in 2003-2016 and dominant directions of migration in 2002-2015. Using Florence's index (1), types of functional specialization of rural areas were determined. This method is based on identifying the dominant elements in the set and on the analysis of similarity, i.e., comparing the shares of a feature of a given unit, in this case rural communes, with the percentage of the same feature but for a hierarchically higher unit. The local specialization index determines the dominant types of economic activity in municipalities. The higher the index value, the higher the degree of specialization.

$$
W_{s l}=\frac{u_{i}}{U_{i}}
$$

where $W_{s l}$ is the index of specialization, $u_{i}$ is the percentage of feature the structure, and $U_{i}$ is the percentage of feature the hierarchically higher structure.

Florence's local specialization index, like any method, has some limitations. In this method, it is necessary to relate the scale of the phenomenon to a hierarchically higher unit. Moreover, it is limited in showing the specialization of the structure, and thus it is an indicator showing the specialization in a generalized way.

Data on land use, in particular on agricultural land from the Central Statistical Office, and unpublished data on land use from the Marshal's Office from 2002 and 2014, as well as data on the size of farms from the General Agricultural Census of 2002 and 2010, were also used. Geoportal ORSIP and Google Maps were used to determine the connections and the strength of economic impacts on the pace of transformation, on the basis of which the location of rural communes in relation to cities in kilometres and the travel time by passenger car in minutes from cities to rural communes were determined. The Pearson correlation index was also calculated for all GZM cities, including large cities, i.e., those over 100,000 .

\section{Rural Areas in Poland and Economic Consequences of Migration}

The economic transformation that started in Poland after 1989 caused changes in rural areas relatively slowly, as it was mainly concentrated in urban areas. In 2019, 15.3 million people lived in the countryside, which is $40 \%$ of the total population and 53 people per $\mathrm{km}^{2}$ [45]. Compared to 2010, the population of rural areas increased by over 240 thousand, with a decrease in urban areas by 360 thousand. Its structure was also slightly younger compared to cities, as the demographic median age was 39.1 [46].

For a long time, villages were perceived as rather homogeneous elements and mainly dependent on agriculture. In the suburban areas, where the city pressure was very high, economic diversification and multifunctionality are clearly visible [11,12]. According to the OECD metropolitan classification, $70 \%$ of the population of Poland lives outside metropoli$\tan$ areas, i.e., outside functional urban areas (MOF) with at least 50,000 inhabitants, but it is in them that strong economic and spatial processes occur-namely suburbanization and periurbanisation. As in other countries, in Poland the villages in the metropolitan hinterland clearly benefit from the proximity to urban agglomerations. Therefore, proper 
management of suburban space in the back of large urban complexes is very important, especially since new types of settlement and very scattered buildings are emerging there. This state of affairs contributes to the uncontrolled development of cities and is a derivative of the lack of a rational spatial policy in Poland [47]. Currently, it is characterized by a low coverage of the land development plans for the invested areas and their low quality as well as a high degree of land fragmentation. This causes spatial chaos [48], landscape changes [18], and huge costs [49].

Decentralization in Poland has increased the importance of voivodships in the implementation of rural development policy, and municipalities have become important actors in providing services to rural residents and providing basic infrastructure. Each region in Poland develops its own strategy. Local governments have in many ways become the main actors in rural development. Despite this, they are often unable to develop an appropriate policy that refers to local factors and their specificity. From a practical point of view, the analysis of strategic documents of rural communes very often shows a mismatch between their environmental and economic characteristics, and their assumptions and actual activities, and yet the rural policy should refer to rural regions according to their characteristics [29]. Therefore, bottom-up cooperation in functional urban areas in Poland is not always properly adjusted to the specificity of a specific area and its scale of local problems [47], as well as in metropolitan areas [50]. The economy of Polish villages is often not planned and steered by local governments in a sustainable manner. Despite this, economic transformations, especially in the hinterland of the largest cities, are very intense [46] and are the result of overlapping factors, among which, apart from the urbanrural migration, the activity of entrepreneurs themselves seems to be important. It is often a bottom-up initiative based on local capital.

Migrations from cities to the countryside play an extremely important role in contemporary processes in the countryside. From the mid-1970s in Poland, the dominant direction of migration was from the countryside to the cities. The direction of migration changed for the first time since the Second World War, and in the year 2000 cities recorded a negative net migration. In the years 1999-2016, upwards of 84 thousand people came to the countryside, with up to 141 thousand migrants annually, compared to 64 thousand in the years 1975-1998 [51]. The main motive for the migration of the inhabitants of Polish cities to the suburbs is the proximity of a large city [52-55], family reasons, affordable land prices [56,57], and the desire for a better quality of life in the rural environment. In contrast some secondary motives include, among others, increasing the area of apartments, the quality of the natural environment, or a greater sense of security [58]. Rural areas accounted for around a quarter of gross domestic product (GDP) [46].

Reversing the migration trend has wide spatial consequences for the countryside [48,55] and functional [59]. Whereas there is a serious concern that the current planning practices may have a negative impact on the next generation due to increasing urbanization and urban sprawl [60], they are nevertheless bringing about positive functional changes and job growth. From the economic point of view, migrants from cities strengthen the social capital of rural areas, influence the professional diversification of the population, and increase entrepreneurship and specialization towards multifunctional development. The high demographic potential of suburban areas is also reinforced by the positive socio-economic characteristics of new residents. As research shows, in comparison to other rural areas, suburban areas have the highest share of people with secondary and higher education and the highest percentage of the self-employed and people with non-agricultural income [61]. Along with the increase in the population in suburban zones, the largest number of companies per 1000 people of working age was recorded as well as their most dynamic growth, which determines the level of socio-economic development and living conditions. In the Silesian Voivodeship in the years 1999 to 2016, 6.4 to 10.8 thousand people have moved to the countryside annually, with 8.8 thousand migrants on average per year. This gives this region the 4th place in Poland in terms of population flows (after the Mazowieckie Voivodeship with 260.5 thousand; Greater Poland Voivodeship with 231 thousand; Dolnoślaskie 
Voivodeship with 171.7 thousand) [54]. Considering the spatial relations in functional urban areas (FUA), the base of the studied area apparently shows a smaller scale of inflow compared to other areas of this type in Poland. However, it should be borne in mind that migrant flows to the countryside in the hinterland of the GZM are spread over a larger area and in a greater number of suburban communes because villages are located in the zone of different cities and not, as in most functional urban areas (FUA) in Poland, around one monocentric centre [52]. Although Bartosiewicz and Marcińczak [62] claimed that the process of deconcentration (suburbanization) in Poland is closely related to the degree of polycentric urban development, and greater deconcentration implies more polycentric urban forms, the phenomenon is regionally very diverse. Nevertheless, several thousand people come to the suburban villages in the study area on a permanent basis each year, and as a rule, they are better educated and economically well off. Hence, in suburban areas, there is an accumulation of social and economic capital conducive to development [1]. Undoubtedly, rural areas are gaining a new economic class.

The research of Pytel $[63,64]$ confirms the attractiveness of rural areas in Poland in the hinterland of large agglomerations also for retirees who contribute to the growth of jobs. It is also seen in different countries. Pensioners contribute to the local development and economic entrepreneurship of the suburban area [65]. Hans and Koster [66] point out in some countries the positive participation of 65+ seniors in setting up start-ups, which may be a form of partial retirement. Sometimes, however, migration from urban to peri-urban regions due to second homes or retirement can directly or indirectly affect the socio-spatial conflicts that make it difficult for new residents to take root. In some areas, local communities may even feel threatened by the "invasion" of newcomers from cities and having different values or approach to business $[67,68]$.

\section{Results}

\subsection{Changes in the Labour Market-Its Size and Dynamics}

The labour market in the back of the GZM is highly diversified. Despite the strong pressure of the surrounding cities, rural areas use local endogenous resources and rely on their own capital. This translates into the economy. All researched rural communes recorded an increase in employed persons in the period 2003-2016. This is an extremely important element proving the good economic condition of this area. The number of employed persons in 2016 was 23.8 thousand people, and in the period of 13 years it increased by 5.7 thousand people, i.e., by $31.4 \%$ (Table 2). Rural communes achieved an average increase in the number of employees by 712 per one commune, i.e., 60 people per year. Dividing the period of changes into two phases, a clear upward trend is observed in the first phase (2003-2010), on average by $25.5 \%$; in individual municipalities the increase is from $13.6 \%$ to $53.8 \%$, while in the second phase (2010-2016), there is a slight weakening and only an increase by $4.7 \%$ (2010-2016). Taking into account the research period for the years 2003-2016, some rural communes increased their local labour markets by as much as $83 \%$ (Table 2). In general, rural areas are small labour markets and are in the range of 1.4 to 5000 people working (Figure 2).

Taking into account the size of the labour markets and their dynamics, the research results indicate that its greatest changes took place in Gierałtowice, which created 1535 jobs and increased its local labour market by $82.7 \%$, and during the entire period of changes, the dynamics remained at a high level (Tables 2 and 3). Very favourable changes in the years 2003-2010 can be observed in Chełm Ślaski. In 2003, it was a small labour market with slightly more than 1000 working jobs, which in 2016 increased to over 1.6 thousand employed by more than $50 \%$. These two communes are economic leaders in the field of labour market transformations in the hinterland of the GZM and can be described as a type of intensive growth. 
Table 2. Local labour market in rural communes in 2003, 2010, and 2016.

\begin{tabular}{|c|c|c|c|c|c|c|c|c|c|}
\hline \multirow{3}{*}{ Commune } & \multicolumn{3}{|c|}{ Employed Persons } & \multicolumn{6}{|c|}{ Increase in the Number of Employed Persons } \\
\hline & \multirow[b]{2}{*}{$2003 *$} & \multirow[b]{2}{*}{$2010 * *$} & \multirow[b]{2}{*}{$2016 * * *$} & \multicolumn{3}{|c|}{ Persons } & \multicolumn{3}{|c|}{ Dynamics of Change } \\
\hline & & & & $\begin{array}{c}2010 \\
2003=100\end{array}$ & $\begin{array}{c}2016 \\
2010=100\end{array}$ & $\begin{array}{c}\text { Total } \\
2003-2016\end{array}$ & $\begin{array}{c}2010 \\
2003=100\end{array}$ & $\begin{array}{c}2016 \\
2010=100\end{array}$ & $\begin{array}{c}2016 \\
2003=100\end{array}$ \\
\hline Bobrowniki & 2624 & 3324 & 2974 & 700 & -350 & 350 & 126.7 & 89.5 & 113.3 \\
\hline Psary & 2446 & 2778 & 2832 & 332 & 54 & 386 & 113.6 & 101.9 & 115.8 \\
\hline Świerklaniec & 3546 & 4798 & 4462 & 1252 & -336 & 916 & 135.3 & 93.0 & 125.8 \\
\hline Zbrosławice & 3597 & 4388 & 5033 & 791 & 645 & 1436 & 122.0 & 114.7 & 139.9 \\
\hline Gierałtowice & 1856 & 2424 & 3391 & 568 & 967 & 1535 & 130.6 & 139.9 & 182.7 \\
\hline Wyry & 1684 & 1913 & 2108 & 229 & 195 & 424 & 113.6 & 110.2 & 125.2 \\
\hline Kobiór & 1368 & 1566 & 1444 & 198 & -122 & 76 & 114.5 & 92.2 & 105.6 \\
\hline Chełm Śląski & 1045 & 1607 & 1622 & 562 & 15 & 577 & 153.8 & 100.9 & 155.2 \\
\hline Total & 18,166 & 22,798 & 23,866 & 4632 & 1068 & 5700 & 125.5 & 104.7 & 131.4 \\
\hline
\end{tabular}

${ }^{*}$ Data from the Central Statistical Office; ${ }^{* *}$ data from the publication [30] (p. 220); ${ }^{* * *}$ estimated data. Source: Own elaboration.
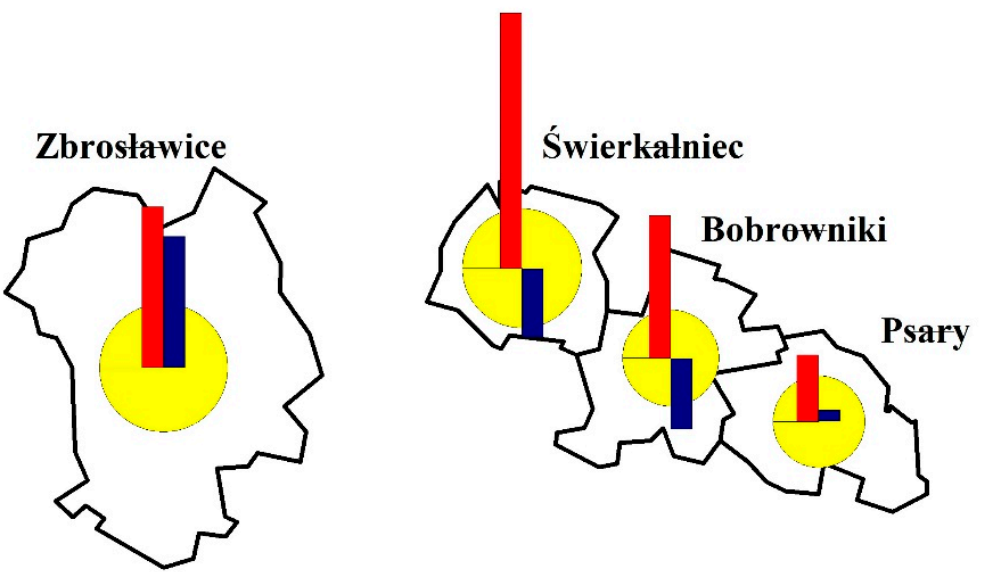

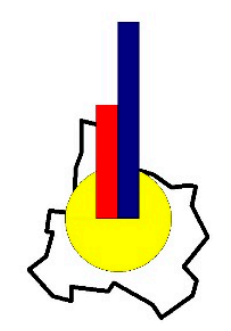

Gierałtowice
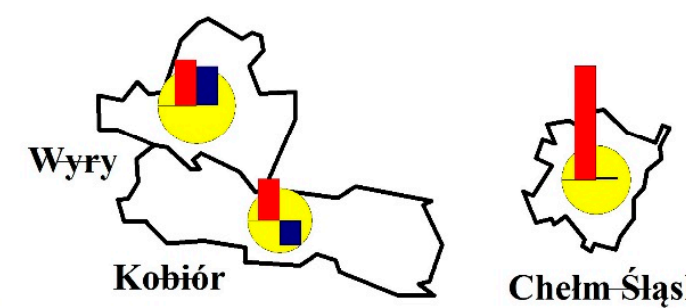

Chelm Śląski

increase/decrease in the number of employed persons
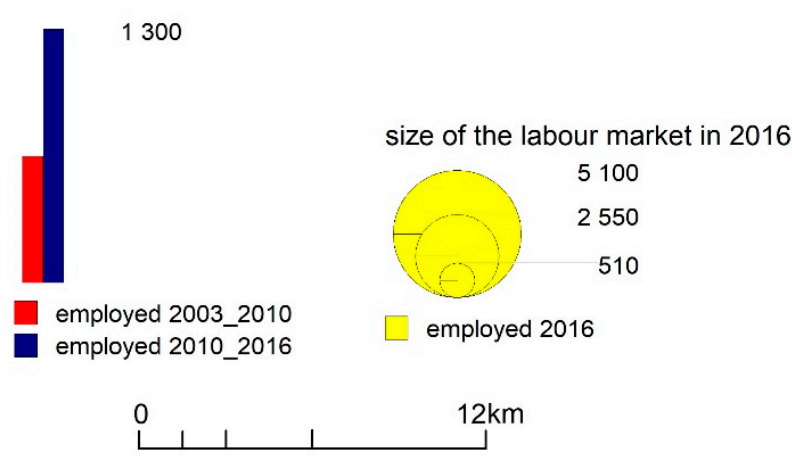

Figure 2. Change in the number of employed persons in the analysed rural communes in the period 2003-2016. Source: Own elaboration. 
Table 3. Types of changes in rural labour markets in the hinterland of the GZM in 2003-2016.

\begin{tabular}{ccccc}
\hline \multirow{2}{*}{$\begin{array}{c}\text { Types of Changes in } \\
\text { the Labour Market }\end{array}$} & Dynamics & \multicolumn{2}{c}{ Years } & \multicolumn{2}{c}{ Labour Market Growth } \\
\cline { 3 - 5 } & & $\mathbf{2 0 0 3 - 2 0 1 0}$ & $\mathbf{2 0 1 0 - 2 0 1 6}$ & Gienałtowice, Chełm Śląski \\
\hline Intense growth & over 140 & Chełm Śląski & - & Zbrosławice \\
High growth & $130-140$ & Gierałtowice, Świerklaniec & Gierałtowice & Świerklaniec, Wyry \\
Moderate growth & $120-130$ & Bobrowniki, Zbrosławice & - & Psary, Bobrowniki \\
Small growth & $110-120$ & Kobiór, Psary, Wyry & Zbrosławice, Wyry & Kobiór \\
Stagnation & $100-110$ & - & Psary, Chełm Śląski & Kobiór, Świerklaniec \\
Weakening & $90-100$ & - & Bobrowniki & - \\
Shrinking & $80-90$ & - & & \\
\hline
\end{tabular}

Source: Own elaboration.

Positive changes also took place in Zbrosławice. These changes represent a high increase in employment by 1.4 thousand jobs (39.9\%). On the other hand, a moderate increase of $25 \%$ was observed in the next two communes, Wyry and Świerklaniec, although in Świerklaniec, after a very dynamic period of changes since 2010, a slightly decreasing employment trend can be seen. The weakest changes were observed in Psary, Bobrowniki, and Kobiórze, where the weakening of the local labour market, and even its shrinking, is visible.

\subsection{Size of Companies and Their Structure}

The structure of the economy is well described by the size of the entities and working in three sectors. One question that arises is, who are the ones creating the economic market in the hinterland of the GZM? Each of the analysed rural areas has its own characteristics, but the main role is played by micro-enterprises up to 9 persons. Comparing 2000 and 2010, the increase in the number of employees was recorded both in small and medium-sized enterprises, and to a lesser extent in large ones. In 2000, employment in companies of up to 9 people ranged from $37 \%$ to $80 \%$ (Table 4, Figure 3). Over the period of 10 years, in most rural areas, their slight but systematic growth was observed, and their share amounted to $43-68 \%$. In two areas, there was a decline in employment in the smallest companies, with a simultaneous increase in employment of more than 20 people, i.e., large entities (Bobrowniki by as much as 16\%) and medium and large entities (Gierałtowice $9 \%$ and $4 \%$, respectively).

The size of the companies has slightly increased over the 10 years. In 2000, small economic entities employed on average 1.5-1.7 persons and 1.6-1.8 in 2010. This trend continued in 2016. Almost all villages recorded an increase in employment also in mediumsized companies from 9 to 20 persons. This is the second visible trend in the hinterland of the GZM; in 2000 this share ranged from $20 \%$ to $36 \%$, and in 2010 it was already ranging from $26 \%$ to $40 \%$, while in 2016 it was from $21 \%$ to $31 \%$.

Table 4. Economic specializations in rural areas in the hinterland of the GZM.

\begin{tabular}{|c|c|c|c|c|c|c|c|c|c|}
\hline \multirow[b]{2}{*}{ Commune } & \multicolumn{9}{|c|}{ Economic Specializations According to PKD Sections } \\
\hline & $\begin{array}{c}\text { Other } \\
\text { Service } \\
\text { Activities }\end{array}$ & Trade & $\begin{array}{c}\text { Scientific and } \\
\text { Professional } \\
\text { Activity }\end{array}$ & $\begin{array}{l}\text { Industrial } \\
\text { Processing }\end{array}$ & $\begin{array}{c}\text { Gastronomy } \\
\text { and Accom- } \\
\text { modation }\end{array}$ & Construction & $\begin{array}{c}\text { Transport } \\
\text { and } \\
\text { Storage }\end{array}$ & Real Estate & Total \\
\hline Świerklaniec & $X$ & $X$ & $X$ & $X$ & $X$ & $X$ & $X$ & $X$ & 8 \\
\hline Zbrosławice & $x$ & $x$ & $X$ & $X$ & $X$ & $x$ & & & 6 \\
\hline Bobrowniki & $X$ & $X$ & & $X$ & & & $X$ & & 4 \\
\hline Gierałtowice & $X$ & $X$ & $X$ & & & & & & 3 \\
\hline Psary & $X$ & & & & $X$ & & & & 2 \\
\hline Wyry & $X$ & & $X$ & & & & & & 2 \\
\hline Kobiór & $X$ & & & & & & & & 1 \\
\hline Chełm Śląski & $X$ & & & & & & & & 1 \\
\hline Razem & 8 & 4 & 4 & 3 & 3 & 2 & 2 & 1 & 27 \\
\hline
\end{tabular}




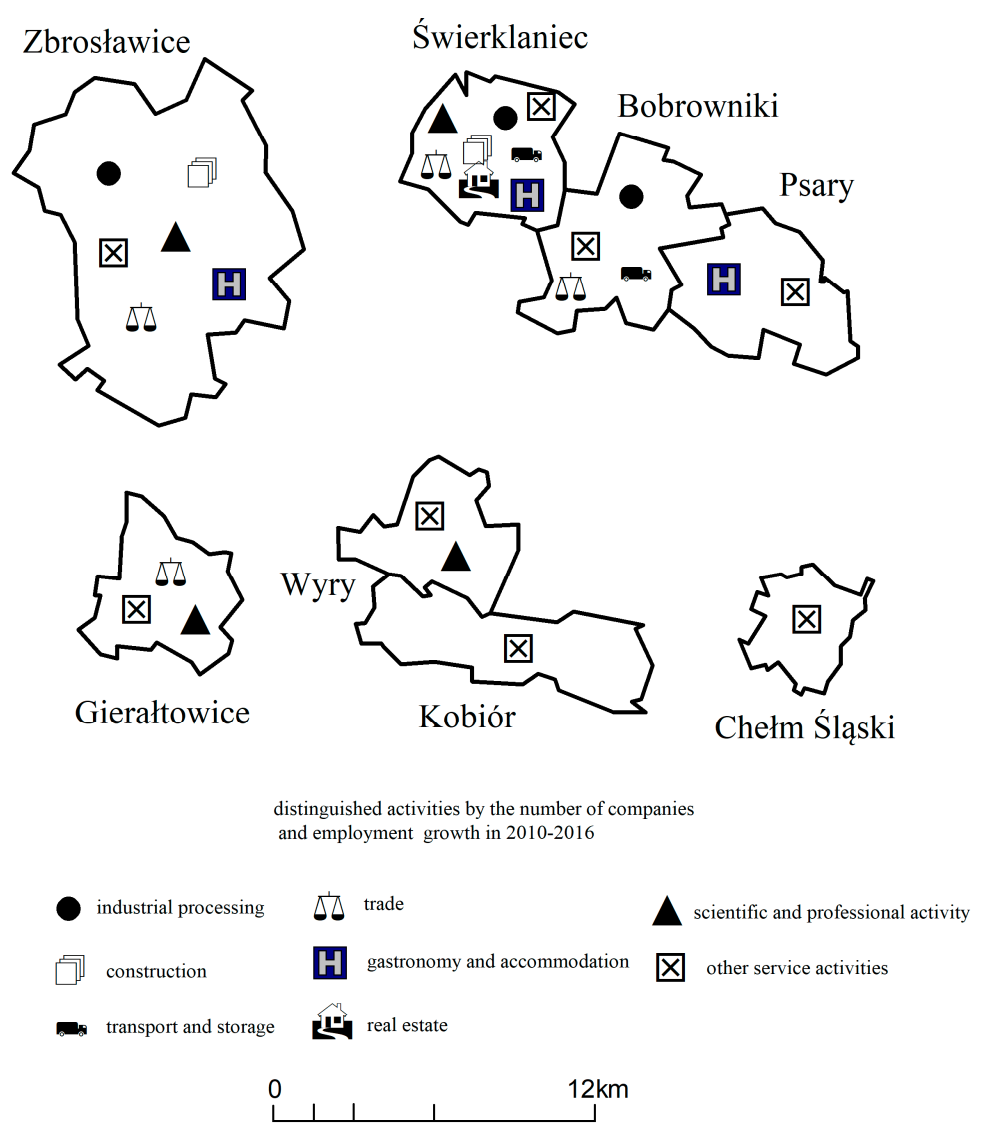

Figure 3. Economic specializations in rural areas in the hinterland of the GZM. Source: Own elaboration.

Taking into account the employment in large economic entities, their participation in 2000 ranged from 5\% to 33\%. It should be noted that in 2000 in four communes, i.e., Świerklaniec, Wyry, Kobiór, and Chełm Ślaski, more people worked in large than in medium-sized workplaces, while in 2010 there was a clear decline in companies of this size ranged from 3\% to 18\%, except for Bobrowniki and Gierałtowice. In 2016 the labour market of large economic entities ranged from $7 \%$ to $20 \%$.

The increase in employment in large business entities is related to new economic investments and the availability of plots of appropriate size for industrial investments as well as the construction of new roads and exits to the A1 and A4 motorways. These investments significantly increased the transport accessibility of rural areas in the hinterland of the GZM, contributing not only to economic urbanization but also to the relocation of residents and suburbanization processes.

The growth of large companies may also be related to the good economic situation of medium-sized enterprises, which, along with the economic development, began to employ more and more employees and thus move from the class of medium-sized enterprises to large enterprises. Another reason may be the growing importance of GZM on the international arena. According to data from 2020, business service centres in core cities concentrated 25.8 thousand jobs in 110 international IT and BPO entities [69-72]. These companies indirectly stimulate other economic sectors in the hinterland of the GZM. More and more service companies are created. It is a sign of the progressive economic development of rural areas towards multifunctional development. Non-agricultural activities (95\% of the total number of employees) dominate, especially in trade, construction, and industrial processing. Trade is a characteristic feature of local labour markets, while industrial processing may be related to various factors, including land ownership and good availability of larger and cheaper plots for investment. Another factor determining the development 
of industrial processing is the proximity of cities and their market, which contributes to specific activities. The communes of Świerklaniec, Bobrowniki, and Zbrosławice recorded a constant increase in the number of people working in manufacturing. Some of these plants are agri-food processing, vegetable growing, and fodder production (Zbrosławice), bakeries, butchers, and slaughterhouses, but there are also various types of industrial processing (Bobrowniki, Świerklaniec) and construction, such as stonework, aggregates for construction, etc. (Zbrosławice, Bobrowniki). There are also catering and accommodation services (Psary, Świerklaniec). The increase in hotel and restaurant activities may be related not only to the course of national roads ( 86 and 78) and the A1 motorway but also to the impact of Katowice International Airport in Pyrzowice, located $10 \mathrm{~km}$ from the analysed communes. The airport influences the development of transport companies and warehouse management (Świerklaniec). On the other hand, the recreational function is rather poorly noticeable in rural areas in the hinterland of the GZM.

In rural areas, there are bussines activities that may be considered quite unusual for these areas, such as financial, insurance, real estate agency services, and professional services (e.g., accounting and bookkeeping activities, advertising). This may have resulted from the impact of large and medium-sized cities that create demand for this type of services, but it may also be associated with an increase in entrepreneurship. The establishment of new companies generates the development of accompanying services. New residents, usually of working age, are prone to set up or move their businesses from their current place of residence, usually from cities to the suburbs. By moving them to the GZM hinterland, the businesses often provide their services to the inhabitants of the metropolis as well, which is confirmed by the unusual bussines activities that are normally considered metropolitan rather than rural (Figure 3). We can refer to the secondary sector and profits from the service sector, which was shifted to the countryside along with immigration in the city-village direction. Financial, insurance, and professional services usually have a supralocal impact and are not able to develop solely into the rural market, where the demand is too small in relation to the supply. Almost throughout the entire research area, there was an increase in other service activities, including repair of computers, personal and household goods, and many other specialized services. The research results show that the economy of rural areas in the hinterland of the GZM is highly diversified. Multifunctionality may also be related to the needs of new residents. Migrations from cities to the countryside change the age structure and education, as well as the population itself. For example, the Wyry commune increased the population by $30 \%$. New residents increase construction traffic (surveying services, construction services, real estate offices, etc.) and generate demand for various services (fitness clubs, private kindergartens, cleaning services).

The structure of land use shows significant spatial transformations of the studied rural communes. In the entire research area, for many years (2002-2014) a decrease in agricultural land by 2219 ha has been observed, specifically a decrease from $2.4 \%$ to $7.6 \%$. In each analysed rural commune, an increase in the share of built-up and urbanized land from $5 \%$ to $15 \%$ was recorded, especially residential land in total by 1389 ha. This is a consequence of migration from cities to rural areas, which leads to the development of new housing, housing, and suburbanization. An important element of spatial and functional changes is the increase in communication areas from 5 to 134 ha, i.e., from $3 \%$ to $75 \%$. In the case of the analysed rural communes, these are areas intended for motorways (Bobrowniki and Zbrosławice), new roads, or motorway junctions (Gierałtowice and Zbrosławice). On the one hand, new road investments are a very important element of development, but on the other hand, they contribute to the transformation of rural areas towards a residential function, as well as economic urbanization and multifunctionality. The area of industrial sites also increased by an average of about 5 ha per commune in the period 2022-2014. However, at the present stage, this phenomenon is still characterized by a slight increase, although it depends on the location and road accessibility. 


\subsection{Entrepreneurship and Specialization}

In the period of 21 years (1995-2016), there was a very large increase in companies (Table 5), and the largest by 63\% took place between 1995 and 2000. In some of the examined communes, e.g., Wyry, which had a low output potential, they increased by $243 \%$. It should be noted that in Poland, there is a three-tier division of the country into voivodships, poviats, and communes, which in turn are divided into urban (city, town), urban-rural (small town surrounded by villages) and rural communes. In the Ślaskie Voivodeship, on average, there are 745 entities per rural commune-area (i.e., comprising the rural communes and the rural part in urban-rural communes); in the analysed area, as many as five had over 1000 companies. Every 10th resident ran a business in 2016 (with an average of 8 people in rural areas in the region).

Table 5. Number of business entities in the researched rural communes in 1995 and 2016.

\begin{tabular}{|c|c|c|c|c|c|c|}
\hline \multirow[t]{2}{*}{ Commune } & \multicolumn{2}{|c|}{$\begin{array}{c}\text { Number of } \\
\text { Economic Entities }\end{array}$} & \multirow{2}{*}{$\begin{array}{c}\text { Increase in the Number of } \\
\text { Economic Entities in \% } \\
2016 \text { (in } \%, 1995=100 \\
\text { as Base) }\end{array}$} & \multicolumn{2}{|c|}{$\begin{array}{l}\text { Index } \\
\text { Entrepreneurship }\end{array}$} & \multirow{2}{*}{$\begin{array}{l}\text { Increase in the Index } \\
\text { of Entrepreneurship } \\
\text { in \% } 2016 \text { (in \%, } \\
1995=100 \text { as Base) }\end{array}$} \\
\hline & 1995 & 2016 & & 1995 & 2016 & \\
\hline Bobrowniki & 579 & 1155 & 99 & 50 & 97 & 94 \\
\hline Psary & 538 & 1224 & 128 & 49 & 102 & 108 \\
\hline Świerklaniec & 524 & 1488 & 184 & 53 & 124 & 134 \\
\hline Zbrosławice & 514 & 1481 & 188 & 32 & 93 & 191 \\
\hline Gierałtowice & 524 & 1053 & 101 & 48 & 89 & 85 \\
\hline Wyry & 227 & 778 & 243 & 37 & 98 & 164 \\
\hline Kobiór & 247 & 545 & 121 & 59 & 111 & 88 \\
\hline Chełm Śląski & 298 & 540 & 81 & 54 & 87 & 61 \\
\hline
\end{tabular}

* Entrepreneurship index-number of business entities per 1000 inhabitants.

Taking into account the dynamics of the increase in the number of business entities over the period of 21 years and the entrepreneurship index, the analysed areas form four groups: with very high economic activity (Wyry and Zbrosławice), with high activity (Świerklaniec, Psary), with medium activity (Kobiór, Gierałtowice, Bobrowniki), and with low economic activity (Chełm Śląski).

By examining the number and types of businesses in individual villages using Florence's local specialization index, the conclusion is that the rural hinterland of GZM, compared to rural areas in the country, shows a specialization in mining and quarrying services (Table 6). Its scope includes activities related to the crushing, grinding, and processing of non-mining minerals, as well as, inter alia, geophysical, geological, and seismic measurements. There is also a high specialization in the field of water supply, sewage, and waste management, which also includes sewage services, water collection and treatment, and services related to waste management.

On the other hand, compared to other rural areas of the Ślaskie Voivodeship, specialization of the surveyed villages in higher-order services not related to agriculture was observed. Florence's local specialization index has some limitations; often the values of the index of individual units differ in a small scale of size. Another disadvantage is that it gives each activity a local weight and does not take into account the differences in the absolute number of employees in the analysed activities. Thus, there are situations where highly specialized activities are characterized by a small scale of the phenomenon to be of significant importance for the economic base.

There is a large specialization differentiation depending on whether the area is located to the north or south of the GZM core and the influence of neighbouring cities (each commune is adjacent to a different city, which together form a multicentre core). Świerklaniec shows a surplus of financial and insurance services, Bobrowniki specializes in mining and quarrying, Psary has a surplus in water supply and sewage management, and Kobiór 
and Zbrosławice specialize in real estate services. Gierałtowice, on the other hand, is characterized by the specialization of professional activities, and Chełm Śląski by a surplus of recreational and cultural companies(Table 6). This diversity relates to a multifunctional labour market and is a consequence of the agglomeration benefits of large cities, which are a key factor of economic growth.

Table 6. P.S. Florence's local specialization index of the researched rural communes by economic entities in 2016.

\begin{tabular}{|c|c|c|c|c|c|c|}
\hline \multirow{3}{*}{$\begin{array}{l}\text { Commune } \\
\text { Bobrowniki }\end{array}$} & \multicolumn{6}{|c|}{ PKD Sections with the Highest Value of Florence Index } \\
\hline & \multicolumn{2}{|r|}{ Poland } & \multicolumn{2}{|c|}{ Silesian Voivodeship } & \multicolumn{2}{|c|}{$\begin{array}{l}\text { Rural Areas of the } \\
\text { Śląskie Voivodeship }\end{array}$} \\
\hline & B-2.36 & Mining and quarrying & $\mathrm{O}-2.23$ & $\begin{array}{c}\text { Public administration } \\
\text { and defence, compulsory } \\
\text { social security }\end{array}$ & B-1.86 & Mining and quarrying \\
\hline Psary & E-2.65 & $\begin{array}{l}\text { Water supply; sewerage, } \\
\text { waste management and } \\
\text { remediation activities }\end{array}$ & E-2.20 & $\begin{array}{c}\text { Water supply; sewerage, } \\
\text { waste management and } \\
\text { remediation activities }\end{array}$ & E-1.76 & $\begin{array}{l}\text { Water supply; sewerage, } \\
\text { waste management and } \\
\text { remediation activities }\end{array}$ \\
\hline Świerklaniec & B-1.82 & Mining and quarrying & S-1.55 & Other service activities & K-1.56 & $\begin{array}{c}\text { Financial and } \\
\text { insurance activities }\end{array}$ \\
\hline Zbrosławice & B-2.45 & Mining and quarrying & A-3.54 & $\begin{array}{l}\text { Agriculture, forestry, } \\
\text { hunting and fishing }\end{array}$ & $\mathrm{L}-2.44$ & $\begin{array}{l}\text { Activities related to the } \\
\text { real estate market }\end{array}$ \\
\hline Gierałtowice & E-1.68 & $\begin{array}{l}\text { Water supply; sewerage, } \\
\text { waste management and } \\
\text { remediation activities }\end{array}$ & S-1.86 & Other service activities & M-1.46 & $\begin{array}{l}\text { Professional, scientific } \\
\text { and technical activities }\end{array}$ \\
\hline Wyry & E-3.41 & $\begin{array}{l}\text { Water supply; sewerage, } \\
\text { waste management and } \\
\text { remediation activities }\end{array}$ & E-2.86 & $\begin{array}{c}\text { Water supply; sewerage, } \\
\text { waste management and } \\
\text { remediation activities }\end{array}$ & E-2.27 & $\begin{array}{l}\text { Water supply; sewerage, } \\
\text { waste management and } \\
\text { remediation activities }\end{array}$ \\
\hline Kobiór & E-2.71 & $\begin{array}{l}\text { Water supply; sewerage, } \\
\text { waste management and } \\
\text { remediation activities }\end{array}$ & E-2.24 & $\begin{array}{c}\text { Water supply; sewerage, } \\
\text { waste management and } \\
\text { remediation activities }\end{array}$ & $\mathrm{L}-2.17$ & $\begin{array}{l}\text { Activities related to the } \\
\text { real estate market }\end{array}$ \\
\hline Chełm Śląski & B-1.72 & Mining and quarrying & S-1.81 & Other service activities & $\mathrm{R}-1.38$ & $\begin{array}{l}\text { Activities related to } \\
\text { culture, entertainment } \\
\text { and recreation }\end{array}$ \\
\hline
\end{tabular}

The structure of business entities indicates the service nature of the hinterland of the GZM. Only $2 \%$ are agricultural activities, while $11 \%$ of the activities are related to industry, and $87 \%$ are service activities.

In the entire rural area of the GZM there are 50 thousand working people, and in the years 2003-2016, a significant increase in the local economy is visible in the studied area. In 2010-2017, employment of more than 9 persons increased by $30 \%$.

\subsection{Agricultural Sector}

The region is distinguished by a low degree of land concentration in agriculture. At present, the spatial structure of agriculture has a mosaic pattern, and this is a consequence of industrial development and urbanization. The number of farms in the entire area decreased. The share of farms producing for the market is small. In the study area, agriculture has not played a significant role as a source of income since the 1980s. In most communes, individual farms of up to 2 ha accounted for $75-95 \%$.

The exception is Zbrosławice, where agricultural specialization is maintained, which results from large-scale, highly commercial and specialized agricultural activities related to earlier traditions in this area. In Zbrosławice and its villages, during the socialized economy, there were over a dozen state agricultural farms, agricultural cooperatives, and agricultural production cooperatives. They have been restructured over a 21-year period. In the commune, $40 \%$ of the land belonged to state production and economic centres. Good conditions for the development of agricultural activities are favourable for the development of large-scale farms cultivating cereals or vegetable growing. Farms and 
agricultural companies do not have much competition in the hinterland of the GZM due to the disappearance of this function in other villages, which are becoming more and more urbanized. The largest number of economic entities in 2016, with 56 of these related to agriculture, was present in the Zbrosławice commune, where an increase by 41 companies was recorded since the beginning of the analysed period. It is a threefold change and the highest increase among the discussed rural communes. As evidenced by earlier studies by E. Dus [69], the Zbrosławice commune belongs to the area with the most favourable conditions for the development of agricultural activity in the Ślaskie Voivodeship. It has a large area, $71 \%$ of agricultural land, and agricultural traditions. It shows changes in the size of farms. Taking into account the change in the area per 1 individual farm in Zbrosławice, an upward trend was observed from 4 ha in 1996 to 24 ha in 2010. The agricultural function is of a specialist nature (e.g., vegetable growing or horticulture). It is partially visible also in Gierałtowice and Świerklaniec, but it does not play a major role, while in the remaining area it is gradually disappearing, i.e., arable land is transformed into wasteland, while meadows and pastures are subject to vegetation succession or transformed into construction areas (namely individual construction). There is a gradual departure from the agricultural function in favour of the housing function and multifunctional development.

\section{Discussion}

The presented research results should be considered in a broader context of the current socio-economic processes relating to rural development opportunities. In recent decades, the influence of metropolisation and globalization on socio-economic processes was particularly important in the countries of Central Europe [69-74]. Strong connections between the examined rural communes and the GZM towns of various sizes were observed. Population migrations showed a positive correlation with cities that have more than 100,000 inhabitants and with poviat towns. Pearson's correlation index for all GZM cities was 0.67 , and for large cities (over 100,000) it was 0.46. It can be concluded that this is related to the next phase of GZM development towards more advanced urbanization processes, i.e., spatial metropolisation processes [40]. This resulted from the transformation of the centrally controlled economy into a free market economy, as well as Poland's accession to the European Union in 2004 and joining the network of European connections [75,76]. Moreover, this results in various new foreign investments in suburban zones and in rural areas $[77,78]$ which are near large settlement complexes that face new challenges [79-81].

Rural areas tend to have fewer economic opportunities due to the dominance of the agricultural function, and in the suburbs they are overshadowed by larger cities, although sometimes they benefit from the borrowed scale effect [82-84]. Rural areas benefit from the functional connections and economic potential of a large, polycentric group of cities, and therefore their economic development paths are varied and represent various qualitative types, depending on the zone of influence in which they lie. The represented types range from intensive and high growth of the labour market (employment growth over $30 \%$ ), to weak and moderate (growth $10-20 \%$ ), and eventually to stagnation (up to $10 \%$ ), with signs of slight weakening and contraction. Some municipalities have almost doubled their local labour market, and leaders have increased it by up to $83 \%$. However, the pace and dynamics of changes varied. The economy of rural areas in the hinterland of the GZM developed better in 2003-2010 than in 2010-2016. This could have been conditioned by Poland's accession to the European Union in 2004 on the one hand, and, on the other hand, by the crisis in 2008, which reached the research area with a delay and caused some activities to slow down. However, the development of the labour market of rural communes coincides with the transformation of the entire area, which from a traditional region based on industry [85-87] is changing into a metropolitan region based on specialized services $[40,42,74]$. The communes in the western and southern parts of the metropolitan area coped better with the changes in the labour market; this may be associated with stronger zones of influence of the surrounding cities and with greater dynamics of population changes and migrations [88-90]. Higher employment growth rates 
of companies may also result from greater entrepreneurship in small and medium-sized rural enterprises [91].

Comparing the dynamics of working people and the population in rural areas, it turns out that there are more new inhabitants than there are jobs. Migration to the suburban area occurs throughout Poland. Agricultural areas around urban agglomerations often cease to function as agricultural, and the hinterland is the most attractive location for the professionally active population [46]. In the years 2003-2016, the migration balance in the analysed communes amounted to over 8 thousand inhabitants [52,89], which certainly has an impact on the local economy and their impact, especially on the service sector. In turn, the labour market increased by 5.7 thousand, so it should be concluded that endogenous capital, based on local labour resources, was supplied with migrants-i.e., exogenous capital that comes from the GZM cities. In economic terms, migration has a positive impact on the local market through interactions with local businesses [92]. Suburbanization processes in the hinterland of the GZM in relation to other agglomerations in Poland $[10,25,78,88,89,93]$ are less dynamic, but the migration flows are significant [54] and multidirectional, due to the polycentric core $[90,94,95]$. Almost every city has an impact on the surrounding rural areas and creates its own zone of influence in rural areas [96]. The factor influencing the connections and the strength of impact, as well as the pace of transformations is, on the one hand, the location of rural communes in relation to cities at a distance of 15 to $23 \mathrm{~km}$, and on the other hand, the travel time from cities to rural communes of up to $40 \mathrm{~min}$ by car according to the isochrone. This factor relates to the concept of the location rent, known as the city rent or agglomeration benefit. Short distances increase the time accessibility to urban labour markets and influence the economic activity of the population and functional connections in the region.

New residents seek contact with nature [97] and build new homes in rural areas, which has social and spatial consequences leading to landscape changes, suburbanization, and periurbanisation. Hence, in suburban areas there is an accumulation of social and economic capital conducive to development. The residential function causes a change in the lifestyle of the village inhabitants $[6,7,25,47,56,98,99]$. These spatial and social conditions, in turn, affect economic changes. Migrants strengthen the local labour market because they bring with them not only social behaviour, but also new types of activity, patterns of entrepreneurship, work organization and, importantly, they fit into the non-agricultural sector. By building social networks, they contribute to multifunctional development, developing new activities in the countryside. This leads to increased economic activity and its diversity, it also affects the succession of functions in rural areas and the growth of the labour market. This process also occurs in other countries. Scottish research confirms that net migration to rural areas has a positive effect on employment and that immigrants are self-employed and generate new jobs [100]. G. Bosworth [92] describes economic growth in the countryside, stimulated by the influx of migration, and describes it with the term "commercial counterurbanisation". His research shows that immigrants in the North East own more than half of rural micro-enterprises and are responsible for much more employment than the entire agricultural sector. Moreover, he draws attention to the two-stage character of this process - extension in time, which is related to the decision to work in the countryside or run a rural business with a delay, several years after the move. Similar studies have highlighted the entrepreneurial potential of immigrants in England [101]. This alludes to the concept of neo-endogenous development, in the context of which new inhabitants of the rural hinterland area coming from cities can become effective endogenous actors. Furthermore, the fact that these individuals tend to be more skilled, have extensive networks and are relatively wealthy means that they increase their human, social and financial capital. Jack and Anderson [102] describe the mechanism by which an entrepreneur becomes part of a local structure. They explain that the factors that accompany this process create a complex system that is difficult to follow. It is important that new entrepreneurs become part of the local economy, and not only be located in it, if they are to have a beneficial effect on the local or regional economy. In addition, local 
connections help to make greater use of some of the local resources and prevent them from being lost to outdoor lands [103]. Proponents of neo-endogenic rural development [92,104] believe that immigrants have the potential to strengthen non-local connectivity while becoming endogenous actors. It depends on whether they build local networks and stay rooted in them. Through links with local networks, local people and enterprises can benefit from many new forms of cooperation, e.g., business and participate in a wider exchange of knowledge, co-create the rural labour market, create amenities in various economic sectors [105]. Regional and rural development policy in Europe increasingly focuses on entrepreneurship to mobilize the endogenous economic potential of rural areas. It contributes to the economic diversity of the countryside and leads to multifunctionality. This is conducive to shaping local markets in the countryside, which are enriched with central services, which in turn influences the creation of supra-local connections with other areas. According to Duś [69], multifunctional development is a derivative of unfavourable conditions for the development of agricultural activity. Already in 1988, it did not play a significant role, and the share of people earning their living from agriculture was and remains at a low level, ranging from 5\% (in Psary, Świerklaniec) to 1\% (in Gierałtowice and Bobrowniki). According to the OECD [46], due to the strong land fragmentation and a large number of very small households in Poland in 2010, more than half of households declared that agricultural income accounted for less than $30 \%$ of their budget. The development of the agricultural function was significantly limited in the hinterland of the GZM, while the agricultural economy was transformed towards a multiarea and specialized one. Only Zbrosławice has an agricultural function, but there also were changes that have occurred, consisting of the specialization of agri-food farms and land consolidation in order to increase labour productivity (increase in the size of farms). The agricultural function in this area results from good agrotechnical conditions and long traditions in land management. Basically, however, the rural labour market develops mainly non-agricultural activities. This is typical for highly developed countries in the world and for metropolitan areas [106]. Rural farming is being replaced by other functions such as housing, recreation, production and services [46]. In recent years, as part of the multifunctional rural development policy, Poland has dynamically developed non-agricultural functions. Both the country and in the hinterland of the GZM, industrial processing, construction, and various services have developed. The most significant increase in employment occurred in six non-agricultural sections, i.e., information and communication (four communes), professional, scientific and technical activities (four communes), real estate services (two communes), accommodation and catering (six communes), public administration (one commune), and transport and storage (one commune). In the countryside, every third person worked in other services and every five in trade [46]. Local trade is still strongly developed, but its structure has also been strongly transformed in recent years as a result of commercialization by large foreign trade concerns [107].

An unusual feature compared to other rural areas in comparison with the country is the specialization in mining and quarrying services. In the past, heavy industry played a significant role in this area [34]. The restructuring has led to the closure of most hard coal mines, steel mills, and other plants in the industrial sector [85]. The old skills and professional relationships of rural residents are still present in the economy of the hinterland. This is due to the fact that many residents of the closer and further hinterland worked in heavy industry. After retiring from mining, at a very young age (40), some of them set up their own companies or continued working in private business, based on the acquired knowledge. These conditions indirectly shape the economic ties resulting from the regional specificity.

Compared to other communes of the entire voivodeship, rural areas in the hinterland of the GZM are also characterized by a greater role of supply, water and sewage services, and waste management. This function seems to coincide with the role of the back office provided by municipal services to the metropolis. On the other hand, when comparing the examined eight communes with other rural communes in the region, each of them has a 
different specialization and surpluses in other areas, as well as its own path dependence, which fit into multifunctionality [79].

The increase in employment and diversification of economic activity of the surveyed communes has various conditions. First of all, an important development factor is the location in the zone of influence of a metropolitan area with a polycentric structure, which includes such cities as Katowice, Tychy, Gliwice, Zabrze, Bytom, Piekary Ślaskie, Sosnowiec, and Siemianowice Ślaskie. Other medium-sized cities also have their spheres of influence. This area, as a complex settlement complex, offers great location advantages [30,108], which is conducive to non-agricultural economic activity. Although key assets for the economy are not only related to location (such as proximity to urban areas) but also to the interaction with globalized space, the example of the hinterland of the GZM shows that concentration of urban centres and migration have a significant impact on the market work $[108,109]$. The appropriate critical mass of the city, in this case an urban complex with a population of 2.2 million, allows the region to participate in an economy based on knowledge and international connections [74]. McCanna and Acsa [110] suggest that agglomerations should be even in the range of 1.5-2 million to fully participate in the processes of globalization. The "borrowed scale" and the access of villages to central institutions and functions of various types as well as the network of large cities give greater urbanization benefits $[83,84]$. Short distances from the city centre favour functional and spatial connections in the GZM, e.g., commuting to work [62,109], as well as the penetration of innovation or the increasingly popular distance work [111]. The typology of communes in Poland according to the range of influence of large cities indicates that the area covered by the analysis is included in the zone of the strongest real impact, which means that it lies in the suburban zone, where the time access (travel time) to the core is up to $40 \mathrm{~min}$ [59]. At the same time, they participate in development processes [11]. This state of affairs is understandable, due to the fact that metropolitan regions are considered innovation centres that benefit from the external effects of knowledge and agglomeration economies [112], and therefore also rural areas located in their hinterland can be classified as those participating in the development process.

The high transport accessibility, road network, and the location of the studied villages at motorway junctions $[36,59]$ also seem important. In general, transport strengthens the functional connections with the city and favours the development of the countryside [113]. Economic activity translates into the growth of industrial areas. In the current phase of spatial development, it is not so noticeable [88], but it clearly shows an upward trend. On the other hand, the growth of communication areas and new road investments made many rural areas available, and this has its spatial (development of suburbanization, landscape changes) and functional consequences (increased economic activity, new industrial and warehouse investments). The implemented road investments will soon activate further transformations of rural land, both for new economic and housing investments. At the present stage of development, large greenfield plants are built in spots and do not form compact zones. The metropolitan area in which this is described is very extensive, and it is expected that large industrial investments, namely those part of the economic urbanization, will become more dynamic within a decade, as is the case in other countries [114-116]. This is a common trend characteristic of areas around large agglomerations in Poland, as well as highly developed countries of the world. The researched rural areas fit into the general trends of land use transformations in terms of transforming agricultural land into other forms of use characteristic of large agglomerations, urban regions, and metropolitan areas. According to Domański et al. [78], the location attractiveness related to the proximity of large cities or main transport routes and a high level of endogenous development are among the most important factors in locating foreign investments in rural areas and small towns in Poland and the reason for their economic success. Foreign investments increase the economic importance of external metropolitan zones. This process has significant consequences for rural metropolitan areas, e.g., having an influence on the intensity and directions of permanent and circular migrations, changes in management, and social changes. 
It cannot be ignored that the rural hinterland of the GZM is located in the subregions of the Śląskie Voivodeship with the highest investment attractiveness for industrial, service, and technologically advanced activities in Poland [117]. The area has a very large investment potential, but currently reserves are still used in more advantageous urban locations and in post-industrial fallow land or in economic zones, guaranteeing investors large tax breaks [118].

\section{Conclusions}

Conclusions of the geographical research presented in the study describes an example of the economic development of a rural area, which allows us to understand the processes of economic urbanization in the back of a large multicentre metropolitan area in Southern Poland. They show micro-spaces from the perspective of multifunctional development and changes in traditional relations between a multicentre urban complex and the countryside.

The analysis provides evidence that the local economy is also developing outside urban centres, where smaller municipalities operate in the shadow of the hierarchy of larger centres [119]. The labour market has grown practically in the entire area. This is important for residents and contributes to their retention in the countryside, reducing depopulation [120]. The dynamics of the labour market is diversified, and each of the municipalities represents slightly different development paths and functional specificity, which were conditioned by various factors. The economic base is formed by production activities and services, and to a small extent by agriculture, which is in line with the trends characteristic of other metropolitan areas in Poland and Europe [46]. These elements should be interpreted as positive signs of a sustainable development that responds to the potential needs of cities, expands new types of activities, and shapes social capital that can support entrepreneurship in new activities in the countryside [113].

Referring to the research hypothesis, it was found that in the hinterland of the GZM there were significant economic changes in line with the process of economic urbanization, which is characterized by an increased labour market based on endogenous capital, which is strengthened by new inhabitants, i.e., migrants from neighbouring cities. The economy is based on micro-enterprises and the growth of medium-sized companies. An important role is played by high entrepreneurship combined with multifunctional development, which is a response to the challenges of modern rural areas in the metropolitan environment. It partly refers to the specificity and genesis of the industrial region, which is transforming into a metropolitan area, as evidenced by quite unusual specializations in the countryside, such as the development of professional or insurance activities.

Although the period of observation of economic processes is relatively short, it can be concluded that the economic growth of rural areas is related to entrepreneurship, convenient location in relation to cities (i.e., a large multicentre core), and migration from cities to villages, which are a derivative of location. Rural areas benefit from the connections of the urban network, implying the creation of an integrated settlement system anchored by the main cities in the region. The impact and the proximity of large centres provide the opportunity to build diverse small local economies that combine to form an element of a larger regional labour market in the Silesian region. Social, economic, and spatial changes, although they occur locally, are associated with hierarchically higher units-namely metropolitan and global [121].

The polycentricity of the structure results in the overlapping of urban impact zones, and this has a positive effect on the development of rural areas, which are characterized by various complementary specialized profiles. This scenario also occurs in other urban areas [28]. Embedding in networks of various scales is characteristic of Europe [122]. Burger and Maijers [84] believed that the economies of scale may create fields of external effects of agglomerations affecting rural areas.

Economic activity and micro-enterprises play an essential role in the hinterland of the GZM, systematically increasing the labour market and diversifying it. Local entrepreneurship partially responds to the needs of a large sales market and fills economic niches. The 
growth of medium-sized companies proves to be a sign of good condition of the local entrepreneurs who show economic progress. It should be noted that it may change over time as a result of broader macroeconomic conditions.

Migrations from cities to the outer zone influence the spatial and functional connections with the metropolitan area, and as a result of this the future villages can gain in innovation and participate in the network of European or global connections. They also strengthen endogenous development [105], the idea of which has become an important paradigm for their economic development.

To sum up, the rural economy in the hinterland of the GZM is in line with the transformations of the entire Silesian region and refers to the national policy on employment and economic development, the common agricultural policy of the European Union and the challenges of the 2030 Agenda, including in the field of economic growth and decent work and sustainable cities and communities (https:/ /www.un.org/sustainabledevelopment/ sustainable-development-goals (accessed on 15 June 2021)).

The obtained results create prospects for further research on the directions of economic development in the countryside in the hinterland of GZM. They also pose challenges related to spatial planning, especially spatial chaos resulting from defective local plans in Poland, as well as inadequate management of public space in a polycentric urban region. The results presented in the article emphasize the need to conduct comparative research in the hinterland of large urban complexes with similar functional and spatial characteristics in other countries of Central and Eastern Europe.

Author Contributions: Conceptualization, E.Z.-Ż.; Data curation, M.D.; Formal analysis, E.Z.-Ż. and M.D.; Investigation, E.Z.-Ż. and M.D.; Methodology, E.Z.-Ż. and M.D.; Project administration, E.Z.-Ż.; Resources, M.D.; Software, M.D.; Supervision, E.Z.-Ż.; Visualization, E.Z.-Ż. and M.D.; Writing-original draft, E.Z.-Ż. and M.D.; Writing-review \& editing, E.Z.-Ż. All authors have read and agreed to the published version of the manuscript.

Funding: This research received no external funding.

Institutional Review Board Statement: Not applicable.

Informed Consent Statement: Not applicable.

Data Availability Statement: Not applicable.

Conflicts of Interest: The authors declare no conflict of interest.

\section{References}

1. Biegańska, J.; Środa-Murawska, S.; Kruzmetra, Z.; Swiaczny, F. Peri-Urban development as a significant rural development trend. Quaest. Geogr. 2018, 37, 125-140. [CrossRef]

2. Caruso, G. Periurbanisation, the Situation in Europe: A Bibliographical Note and Survey of St. Udies in the Netherlands, Belgium, Great Britain, Germany, Italy and the Nordic Ountries. Final Report; DATAR: Dijon, France, 2001; pp. 1-172.

3. Kostelecký, T.; Čermák, D. Metropolitan Areas in the Czech Republic-Definitions, Basic Characteristics, Patterns of Suburbanisation and Their Impact on Political Behavior; Sociological Studies: Praha, Czech Republic, 2004; pp. 7-57.

4. Leetmaa, K.; Tammaru, T. Suburbanization in countries in transition:Destinations of suburbanizers in the Tallinn metropolitan area. Geogr. Ann. Ser. B Hum. Geogr. 2007, 89, 127-146. [CrossRef]

5. Hirt, S. Suburbanizing Sofia: Characteristics of post-socialist peri-urban change. Urban Geogr. 2007, 28, 755-780. [CrossRef]

6. Zborowski, A.; Soja, M.; Łobodzińska, A. Population trends in Polish cities-Stagnation, depopulation or shrinkage. Pr. Geogr. Inst. Geogr. Gospod. Przestrz. UJ 2012, 130, 7-28. [CrossRef]

7. Zborowski, A.; Raźniak, P. Suburbanizacja rezydencjonalna w Polsce ocena procesu (Residential Suburbanization In Poland. Estimate Of Process). Studia Miej. 2013, 9, 37-50.

8. Grochowski, M.; Korcelli, P.; Kozubek, E.; Sławiński, T.; Werner, P. Peri-urban futures: Scenarios and models for land use change in Europe. In Peri-Urban Futures: Scenarios and Models for Land Use Change in Europe; Nilsson, K., Pauleit, S., Bell, S., Aalbers, C., Sick Nielsen, T., Eds.; Springer: Berlin/Heidelberg, Germany, 2013; pp. 131-167.

9. Pichler-Milanović, N. Confronting suburbanization in Ljubljana. In Confronting Suburbanization: Urban Decentralization in Postsocialist Central and Easter Europe; Stanilov, K., Sýkora, L., Eds.; Wiley-Blackwell: Chichester, UK, 2014; pp. 65-96.

10. Lisowski, A.; Mantey, D.; Wilk, W. Lessons from Warsaw. In Confronting suburbanization: Urban Decentralization in Postsocialist Central and Easter Europe; Stanilov, K., Sýkora, L., Eds.; Wiley-Blackwell: Chichester, UK, 2014; pp. 225-255. [CrossRef] 
11. Bański, J.; Mazur, M. Classification of rural areas in Poland as an instrument of territorial policy. Land Use Policy 2016, 54, 1-17. [CrossRef]

12. Śleszyński, P.; Komornicki, T. Klasyfikacja funkcjonalna gmin Polski na potrzeby monitorowania planowania przestrzennego. Przegląd Geogr. 2016, 88, 469-488. [CrossRef]

13. Konecka-Szydłowska, B.; Maćkiewicz, B. Endogenous capital of small towns in the Poznań agglomeration. In Development Problems; Kwiatek-Sołtys, A., Ed.; Wydawnictwo Annales Universitatis Paedagogicae Cracoviensis, Studia Geographica VIII: Kraków, Poland, 2015; Volume 178, pp. 80-95.

14. Konecka-Szydłowska, B. Significance of small towns in the process of urbanisation of the Wielkopolska region (Poland). Eur. Countrys. 2016, 8, 444-461. [CrossRef]

15. Antrop, M. Landscape change and the urbanization process in Europe. Landsc. Urban Plan. 2004, 67, 9-26. [CrossRef]

16. Vaishar, A.; Zapletalova, J. Sustainable development of the Moravian countryside. J. Geogr. 2010, 5-1, 43-54.

17. Vaishar, A.; Jakesova, L.; Naplavova, M. Current problems in the South-Moravian rural landscape. Eur. Countrys. 2011, 4, 265-281. [CrossRef]

18. Myga-Piatek, U. Landscape management on post-exploitation lands on the example of the Silesian region Poland. Environ. Socio-Econ. Stud. 2014, 2, 1-8. [CrossRef]

19. Kovács, Z. New post-socialist urban landscapes: The emergence of gated communities in East Central Europe. Cities 2014, 36, 179-181. [CrossRef]

20. Kovács, Z.; Farkas, Z.J.; Egedy, T.; Kondor, A.C.; Szabó, B.; Lennert, J.; Kohán, B. Urban sprawl and land conversion in post-socialist cities: The case of metropolitan Budapest. Cities 2019, 92, 71-81. [CrossRef]

21. Šveda, M.; Madajová, M.; Podolák, P. Behind the differentiation of suburban development in the hinterland of Bratislava, Slovakia. CzechSociol. Rev. 2016, 52, 893-925. [CrossRef]

22. Pukowiec-Kurda, K. Landscape texture in anthropogenically transformed regions: The example of upper silesia and the Dabrowa coal basin (southern Poland). Geogr. Pol. 2018, 91, 489-500. [CrossRef]

23. Myga-Piatek, U.; Żemła-Siesicka, A.; Pukowiec-Kurda, K.; Sobala, M.; Nita, J. Is there urban landscape in metropolitan areas? An unobvious answer based on corine land cover analyses. Land 2021, 10, 51. [CrossRef]

24. Champion, A. Europe's Rural Demography. In International Handbook of Rural Demography; László, J., Kulcsár, K., Curtis, J., Eds.; Springer: Berlin/Heidelberg, Germany, 2012; Volume 9, pp. 81-93.

25. Raźniak, P.; Winiarczyk-Raźniak, A. Spatial distribution and differences in migration patterns and revenues of gminas in the Kraków Metropolitan Area. Bull. Geography. Socio-Econ. Ser. 2013, 19, 73-86. [CrossRef]

26. OECD Regional Outlook 2016. Productive Regions for Inclusive Societes. Available online: https://www.oecd.org/regional/ oecd-regional-outlook-2016-9789264260245-en.htm (accessed on 15 February 2021).

27. Eurostat. Recycling Rate of Municipal Waste. 2019. Available online: https://ec.europa.eu/eurostat/databrowser/view/t2020_ rt120/default/table?lang=en (accessed on 21 January 2021).

28. Meijers, E.; Wouw, D. Struggles and strategies of rural regions in the age of the 'urban triumph'. J. Rural. Stud. 2019, 66, 21-29. [CrossRef]

29. Kahila, P.; Rauhut, D. Labour demand and labour market institutions in rural areas. Rom. J. Reg. Sci. 2015, 9, 19-38.

30. Kłosowski, F.; Pytel, S.; Runge, A.; Sitek, S.; Zuzańska-Żyśko, E. Rynek Pracy w Subregionie Centralnym Województwa Śląskiego; Prace Wydziału Nauk o Ziemi Uniwersytetu Śląskiego: Sosnowiec, Poland, 2013; pp. 135-142.

31. Bański, J.; Stola, W. Przemiany Struktury Przestrzennej i Funkcjonalnej Obszarów Wiejskich w Polsce, 3rd ed.; Studia Obszarów Wiejskich, Komisja Obszarów Wiejskich, Polskie Towarzysto Geograficzne: Warszawa, Poland, 2002; pp. 7-111.

32. Runge, A.; Runge, J. Conditins of Regional Development of Moravian Silesian Province (the Czech Republic) and Silesian voivodship (Poland). In Problems of Regional Development in Border Regions of Ukraine and Poland; Palmowski, T., Matviyishyn, Y., Eds.; Regional Institute of Public Administration: Lviv, Ukraine, 2006; pp. 169-189.

33. Tkocz, M.; Rechłowicz, M. Directions in development of the old industrial region in the 21st century. The example of upper Silesia Industrial District. In Strategia Optymalnego Rozwoju; Bakirow, B.C., Ed.; Charkowski Nacjionalnyj Uniwersytet: Charków, Ukraina, 2011; pp. 192-195.

34. Tkocz, M. Tradycyjny okreg przemysłowy z perspektywy 25-lecia funkcjonowania w gospodarce w Polsce. Przykład Górnośląskiego Okregu Przemysłowego. Pr. Kom. Geogr. Przemystu Pol. Tow. Geogr. 2015, 29, 112-126.

35. Krzysztofik, R.; Spórna, T.; Runge, J.; Kantor-Pietraga, I. Characteristic features of urbanization on the area of silesian province (Poland) on the beginning of 21st century. Rom. Sociol. 2011, 3, 56-66.

36. Soczówka, A. Zróżnicowanie Struktury Przestrzennej Komunikacji Miejskiej w Konurbacji Katowickiej; Wydział Nauk o Ziemi UŚ: Sosnowiec, Poland, 2012; pp. 1-243.

37. Sagan, R.; Sitek, S.; Szajnowska-Wysocka, S. The impact of globalisation on regional identity: The example of Silesian identity. Bull. Geography. Socio-Econ. Ser. 2020, 48, 83-111. [CrossRef]

38. Klasik, A. Aktywność przedsiębiorcza i konkurencyjność ekonomiczna miast w procesie restrukturyzacji aglomeracji miejskich. Podstawy koncepcyjnometodologiczne. In Aktywność Przedsiębiorcza i Konkurencyjność Ekonomiczna Miast w Procesie Restrukturyzacji Aglomeracji Miejskich; Klasik, A., Ed.; Akademia Ekonomiczna w Katowicach: Katowice, Poland, 2008 ; pp. 17-50.

39. Petryszyn, J. Główne centra Metropolii "Silesia”. Acta Geogr. Sil. 2011, 10, 36-44.

40. Zuzańska-Żyśko, E. Procesy Metropolizacj; Teoria i praktyka, PWN: Warszawa, Poland, 2016; pp. 1-432. 
41. Górnośląsko-Zagłębiowska Metropolia. Available online: https://metropoliagzm.pl/ (accessed on 18 February 2021).

42. Petryszyn, J.; Zuzańska-Żyśko, E. Od funkcji przemysłowej do turystycznej—przykład Ustronia. In Funkcja Turystyczna Miast; Jażdżewska, I., Ed.; XXI Konwersatorium Wiedzy o Mieście, Uniwerystet Łódzki: Łódź, Poland, 2008; pp. 133-144.

43. Szajnowska-Wysocka, A.; Zuzańska-Żyśko, E. The Upper-Silesian conurbation on the path towards the "Silesia" metropolis. Bull. Geography. Socio-Econ. Ser. 2013, 21, 111-124. [CrossRef]

44. Główny Urząd Statystyczny. Available online: www.stat.gov.pl (accessed on 25 January 2021).

45. Demographic Yearbook of Poland. GUS, Warszawa. 2020. Available online: https://stat.gov.pl/en/topics/statistical-yearbooks/ statistical-yearbooks / demographic-yearbook-of-poland-2020,3,14.html (accessed on 27 January 2021).

46. OECD Rural Policy Reviews: Poland. 2018. Available online: https:/ /www.oecd.org/publications/oecd-rural-policy-reviewspoland-2018-9789264289925-en.htm (accessed on 3 February 2021).

47. Kaczmarek, T. Functional urban areas as the focus of development policy in Poland. Rozw. Reg. Polityka Reg. 2015, 29, 9-19. [CrossRef]

48. Śleszyński, P.; Kowalewski, A.; Markowski, T.; Legutko-Kobus, P.; Nowak, M. The contemporary economic costs of spatial chaos: Evidence from Poland. Land 2020, 9, 214. [CrossRef]

49. Lityński, P.; Hołuj, A. Koszty migracji wahadłowych ze strefy podmiejskiej do miasta rdzeniowego ośrodków wojewódzkich. Studia KPZK PAN 2008, 182, 114-162.

50. Kaczmarek, T.; Mikuła, Ł. Metropolitan integration in Poland: The case of Poznań Metropolis. Int. Plan. Stud. 2017, $22,30-43$.

51. Migracje Wewnętrzne Ludności na Pobyt Stały Według Województw w Latach 1974-2016 (Internal Migrations of the Population, 2017). Available online: https://stat.gov.pl/obszary-tematyczne/ludnosc/migracje-wewnetrzne-ludnosci/migracjewewnetrzne-ludnosci-na-pobyt-staly-wedlug-wojewodztw-w-latach-1974--2016,3,1.html (accessed on 23 May 2021).

52. Dyszy, M.; Zuzańska-Żyśko, E. Migrations of Population to Rural Areas as Suburbanization Development Factor (Sub-Urban Areas) in Górnośląsko-Zagłębiowska Metropolis. In 4th International Scientific Conference GEOBALCANICA Proceedings; Geobalcanica Society: Ohrid/Skopje, Republic of Macedonia, 2018; pp. 325-334.

53. Zborowski, A.; Pawlak, H.; Gałka, J. Relacje społeczne między mieszkańcami wsi i ludnością napływową z miasta w strefie podmiejskiej Krakowa-Przestrzeń konfliktu czy współpracy? Konwersatorium Wiedzy Mieście 2019, 4, 51-63. [CrossRef]

54. Trzepacz, P.; Janas, K.; Piech, K. Migracje z udziałem ludności miast Polski w latach 2006-2016. In Przemiany Demograficzne Miast Polski. Wymiar krajowy, Regionalny i Lokalny; Krajowy Instytut Polityki Przestrzennej i Mieszkalnictwa: Kraków, Poland, 2019; pp. 47-61.

55. Śleszyński, P. Directions of migration registered in the Warsaw Metropolitan Area. In Internal Migrations in Poland; Skoczylas, Ł., Smolarkiewicz, E., Eds.; Migration-Ethnicity-Nation: Studies in Culture, Society and Politics: Berlin, Germany, 2019; Volume 9, pp. 97-117.

56. Wójcik, M. Przemiany Społeczno-Przestrzenne Osiedli Wiejskich. Studium Przypadku Łódzkiego Obszaru Metropolitalnego; Uniwersytet Łódzki: Łódź, Poland, 2013; pp. 1-166. [CrossRef]

57. Zuzańska-Żyśko, E. The real estate market in the upper-silesian metropolitan area. Procedia: Soc. Behavior. Sci. 2012, 120, 374-385. [CrossRef]

58. Harańczyk, A. Procesy suburbanizacji w Krakowskim Obszarze Funkcjonalnym (Suburbanisation processes in the Cracow Functional Area). Studia Miej. 2015, 18, 85-102. [CrossRef]

59. Komornicki, T.; Śleszyński, P. Typologia obszarów wiejskich pod względem powiązań funkcjonalnych i relacji miasto-wieś. In Analiza Zróżnicowania i Perspektyw Rozwoju o Obszarów Wiejskich w Polsce do 2015 Roku; Bański, J., Ed.; Studia Obszarów Wiejskich: Warszawa, Poland, 2009; Volume 6, pp. 9-37.

60. ESPON. Policy Brief. Reuse of Spaces and Buildings. 2020. Available online: https://www.espon.eu/reuse-spaces-and-buildings (accessed on 7 April 2021).

61. Biegańska, J.; Szymańska, D. The scale and the dynamics of permanent migration in rural and peri-urban areas in Poland-Some problems. Bull. Geography. Socio-Econ. Ser. 2013, 21, 21-30. [CrossRef]

62. Bartosiewicz, B.; Marcińczak, S. Investigating polycentric urban regions: Different measures-Different results. Cities 2020, 105, 102855. [CrossRef]

63. Pytel, S.; Rahmonov, O. Migration processes and the underlying reasons: A study on pensioner migrants in Poland. Popul. Space Place 2019, 25, e2197. [CrossRef]

64. Pytel, S.; Rahmonov, O.; Ruman, M. Internal and external migrations of pensioners in Poland: A directional typology. Popul. Space Place 2020, 26. [CrossRef]

65. Deller, S. Rural entrepreneurship and migration. J. Rural. Stud. 2018, 66, 30-42. [CrossRef]

66. Hans, L.; Koster, S. Urbanization and start-up rates in different geographies: Belgium, the Netherlands, and Sweden. Small Bus. Econ. 2018, 51, 1033-1054. [CrossRef]

67. DuPuis, E.M. Landscapes of Desires? In The Handbookof Rural Studies; Cloke, P., Marsden, T., Mooney, P., Eds.; Sage: London, UK, 2006; pp. 124-132.

68. Ulrich-Schad, J.D. Recreational amenities, rural migration patterns and the great recession. Popul. Environ. 2015, 37, 157-180. [CrossRef]

69. Duś, E. Uwarunkowaia rozwoju rolnictwa w województwie śląskim. Acta Geogr. Sil. 2008, 3, 19-26. 
70. ABSL. Sektor Nowoczesnych Uslug Biznesowych w Polsce; Association of Business Service Leaders: Warsaw, Poland, 2020. Available online: https://absl.pl/pl/news/c/raporty (accessed on 30 October 2020).

71. Dorocki, S.; Raźniak, P.; Winiarczyk-Raźniak, A. Changes in the command and control potential of european cities in 2006-2016. Geogr. Pol. 2019, 92, 275-288. [CrossRef]

72. Raźniak, P.; Dorocki, S.; Winiarczyk-Raźniak, A. Economic resilience of the command and control function of cities in Central and Eastern Europe. Acta Geogr. Slov. Geogr. Zb. 2020, 60, 95-105. [CrossRef]

73. Namyślak, B. Barriers to the development of creative clusters in Poland. Reg. Stud. Reg. Sci. 2020, 412-427. [CrossRef]

74. Zuzańska-Żyśko, E. Role of advanced producer services shaping globalization processes in a post-industrial region: The case of the Górnośląsko-Zagłębiowska Metropolis. Sustainability 2021, 13, 211. [CrossRef]

75. Kamińska, W.; Mularczyk, M. Evaluation of changes in economic and infrastructural development level in rural areas in Poland in the context of EU cohesion policy. Геология геоэкология эволюционная географияНеrzen Univ. St. Petersburg 2014, 12, 315-322.

76. Brambert, P.; Kiniorska, I. Changes in the standard of living in rural population of Poland in the EU membership. Eur. Countrys. 2018, 10, 263-279. [CrossRef]

77. Domański, B. Foreign manufacturing investment in rural Poland: Regularities and conditions. In Local Economy and Urban Development in Poland; Marszał, T., Ed.; Uniwersytet Łódzki: Łódź, Poland, 2000; pp. 40-51.

78. Domański, B.; Pavlínek, P.; Guzik, R. Industrial upgrading through foreign direct investment in central european automotive manufacturing. Eur. Urban Reg. Stud. 2009, 16, 43-63.

79. Gannon, A. Rural tourism as a factor in rural community economic development for economies in transition. J. Sustain. Tour. 1994, 2, 51-60. [CrossRef]

80. Heffner, K.; Marszał, T. Uwarunkowania rozwoju i zmiany w zagospodarowaniu małych miast w Polsce w drugiej połowie XX w. In Uwarunkowania Rozwoju Małych Miast; Heffner, K., Marszał, T., Eds.; Biuletyn KPZK: Warszawa, Poland, 2006; Volume 226, pp. 7-20.

81. Woods, M. Engaging the global countryside: Globalization, hybridity and the reconstitution of rural place. Prog. Hum. Geogr. 2007, 31, 485-507. [CrossRef]

82. Glaeser, E.L. The Triumph of the City: How Our Greatest Invention Makes Us Richer, Smarter, Greener, Healthier and Happier; New York Times: New York, NY, USA, 2012; pp. 1-352.

83. Meijers, E.; Burger, M.; Hoogerbrugge, M. Borrowing size in networks of cities: City size, network connectivity and metropolitan functions in europe. Pap. Reg. Sci. 2016, 95, 181-198. [CrossRef]

84. Burger, M.; Meijers, E. Agglomerations and the rise of urban network externalities. Pap. Reg. Sci. 2016, 95, 5-15. [CrossRef]

85. Riley, R.; Tkocz, M. Coal mining in Upper Silesia under communism and capitalism. Eur. Urban Reg. Stud. 1998, 5, 217-235. [CrossRef]

86. Zuzańska-Żysko, E. Economic transformation of small silesian towns in the years 1990-1999. Geogr. Pol. 2005, 1, 36-149.

87. Krzysztofik, R.; Tkocz, M.; Spórna, T.; Kantor-Pietraga, I. Some dilemmas of post-industrialism in a region of traditional industry: The case of the Katowice conurbation, Poland. Morav. Geogr. Rep. 2016, 24, 42-54. [CrossRef]

88. Dyszy, M. Changes in land usage of rural areas in suburban area of Katowice conurbation. In 4th International Scientific Conference GEOBALCANICA Proceedings; Sociological Studies: Ohrid/Skopje, Republic of Macedonia, 2018; pp. 251-260.

89. Spórna, T. The suburbanisation process in a depopulation context in the Katowice conurbation, Poland. Environ. Socio-Econ. Stud. 2018, 6, 57-72. [CrossRef]

90. Spórna, T.; Krzysztofik, R. 'Inner' suburbanisation-Background of the phenomenon in a polycentric, post-socialist and postindustrial region. Example from the Katowice conurbation, Poland. Cities 2020, 104, 102789. [CrossRef]

91. Keeble, D.; Tyler, P. Enterprising behaviour and the urbanrural shift. Urban Stud. 1995, 32, 975-997. [CrossRef]

92. Bosworth, G. Commercial counterurbanisation: An emerging force in rural economic development. Environ. Plan. 2010, 42, 966-981. [CrossRef]

93. Kiniorska, I. Internal development conditions in rural areas of Eastern Poland. Studia Reg. 2014, 39, $209-219$.

94. Runge, A. Changeability of social-economic factors in the development of population transformations of silesian towns. Bull. Geogr. 2006, 5, 51-64.

95. Zuzańska-Żyśko, E.; Pytel, S.; Koman, W. Suburbanization in Postindustrial Area. Case Study of The Silesia Metropolitan Region. In Proceedings of the GeoMed 2016, 4th International Geography Symposium 2016, Antalya, Turkey, 23-26 May 2016.

96. Dyszy, M.; Zuzańska-Żyśko, E. Strefa wpływu miast a migracje ludności w regionie policentrycznym. Konserw. Wiedzy Mieście 2020, 5, 21-34.

97. Bijker, R.; Haartsen, T.; Strijker, D. Migration to less popular rural areas in the Netherlands: Exploring the motivations. J. Rural. Stud. 2012, 28, 490-498. [CrossRef]

98. Heffner, K.; Gibas, P. Functional areas in the regions and their links to scope sub-regional centres impact. Studia Reg. 2016, 46, 27-39. [CrossRef]

99. Biegańska, J. Społeczno-Geograficzny Wymiar Przemian Stref Podmiejskich w Polsce, 1st ed.; UMK: Torun, Poland, $2019 ;$ pp. 9-197.

100. Findlay, A.; Short, D.; Stockdale, A. The labour market impact of migration to rural areas. Appl. Geogr. 2000, 20, 333-348. [CrossRef]

101. Stockdale, A. Incomers: Offering economic potential in rural England. J. R. Agric. Soc. Engl. 2005, 166, 119-133.

102. Jack, S.; Anderson, A. The effects of embeddedness on the entrepreneurial process. J. Bus. Ventur. 2002, 17, 467-487. [CrossRef] 
103. Courtney, P.; Lepicier, D.; Schmitt, B. Spatial patterns of production linkages in the context of Europe's small towns; how are rural firms linked to the local economy? Reg. Stud. 2007, 42, 355-374. [CrossRef]

104. Lowe, P.; Ray, C.; Ward, N.; Wood, D.; Woodward, R. Participation in Rural Development: A Review of European Experience; School Agriculture, Food and Rural Development, University of Newcastle: Newcastle, UK, 1998; pp. 1-90.

105. Bosworth, G.; Willett, J. Embeddedness or escapism? Rural perceptions and economic development in Cornwall and Northumberland. Sociol. Rural. 2011, 51, 195-214. [CrossRef]

106. Westlund, H.; Nilsson, P. Agriculture's transformation and land-use change in a post-urban world: A case study of the Stockholm region. J. Rural. Stud. 2019, 7, 1-14. [CrossRef]

107. Twardzik, M.; Heffner, K. Small towns and rural areas-As a prospective place of modern retail trade formats in Poland. Eur. Countrys. 2019, 11, 74-84. [CrossRef]

108. Sitek, S.; Zuzańska-Żyśko, E. Classification of labour markets in the Silesian Province (Poland). Environ. Socio-Econ. Stud. 2015, 3, 43-52. [CrossRef]

109. Zuzańska-Żyśko, E. Polycentricity and commuting. An aplication to metropolitan areas in the south of Poland. Acta Geobalcanica 2018, 4-2, 77-84. [CrossRef]

110. McCann, P.; Acs, Z. Globalization: Countries, cities and multinationals. Reg. Stud. 2011, 45, 17-32. [CrossRef]

111. Anas, A. Dlaczego czasy podróży miejskich są tak stabilne? J. Reg. Sci. 2015, 55, 230-261. [CrossRef]

112. Todtling, F.; Trippl, M. One size fits all? Towards a differentiated regional innovation policy approach. Res. Policy 2005, 34, 1203-1219.

113. Chen, Z.; Liu, Y.; Feng, W.; Li, Y.; Li, L. Study on spatial tropism distribution of rural settlements in the Loess Hilly and Gully Region based on natural factors and traffic accessibility. Energy Procedia 2019, 157, 1266-1277. [CrossRef]

114. Hamilton, F.E.I. Transformation and space in central and eastern europe. Geogr. J. 1999, 165, 135-144. [CrossRef]

115. Kubeš, J. European post-socialist citiesand their near hinterland in intra-urban geography literature. Bull. Geography. Socio-Econ. Ser. 2013, 19, 19-43.

116. Timár, J.; Váradi, M.M. The uneven development of suburbanization during transition in Hungary. Eur. Urban Reg. Stud. 2001, 8, 349-360. [CrossRef]

117. Atrakcyjności Inwestycyjna Województw i Podregionów Polski 2016, Instytut Badań nad Gospodarką Rynkową. 2016. Available online: http:/ / www.ibngr.pl/Media/Files / Atrakcyjnosc-inwestycyjna-2016-raport (accessed on 13 April 2021).

118. Kłosowski, F. Usługi w restrukturyzujaccym się regionie tradycyjnym—Przykład konurbacji katowickiej. Space Soc. Econ. 2008, 8, 67-78.

119. Kull, M. Local and regional governance in Finland. A study on institutionalisation, transformation and europeanization. Halduskultuur 2009, 10, 22-39.

120. Rizzo, A. Declining, transition and slow rural territories in southern Italy: Characterizing the intra-rural divides. Eur. Plan. Stud. 2016, 24, 231-253. [CrossRef]

121. Haas, T.; Westlund, H. In the Post-Urban World: Emergent Transformation of Cities and Regions in the Innovative Global Economy, 1st ed.; Urban-Rural Relations in the Post-Urban World, Regional Studies Association, Routledge: London, UK, $2017 ;$ pp. 70-81.

122. Greenberg, Z.; Farja, Y.; Gimmon, E. Embeddedness and growth of small businesses in rural regions. J. Rural. Stud. 2018, 62, 174-182. [CrossRef] 